\title{
Redes interdiscursivas, cenografia e ethos discursivo no funcionamento de práticas discursivas produzidas por indígenas
}

Adriana RECLA

\section{Considerações iniciais}

O presente capítulo tem como tema o estudo das redes interdiscursivas, cenografia e ethos discursivo no funcionamento de práticas discursivas, escritas em Língua Portuguesa, produzidas por sujeitos da população indígena tupiniquim ${ }^{39}$, localizada no município de Aracruz, no estado do Espírito Santo (ES).

39 Considerados os últimos de seu povo, os tupiniquins são importantes guardadores de práticas discursivas indígenas das aldeias Pau-Brasil, Caieiras Velhas, Irajá e Comboios, as quais ainda conservam a cultura, a história, as relações de interação e de intercâmbio, bem como o sistema de valores indígenas dos tupiniquins (TEAO \& LOUREIRO, 2009). Apesar de encontrarmos na maioria dos registros bibliográficos a escrita tupiniquim, optaremos pela forma tupiniquim (HOUAISS, 2009). 
A possibilidade de examinar discursos produzidos por indígenas moveu-nos a lançar um olhar, do ponto de vista linguístico-discursivo, sobre as práticas discursivas dessa população, o que nos revelou o discurso como produto da sociedade, delimitado em um espaço e tempo.

Os discursos proferidos pelos tupiniquins só fazem sentido quando se leva em consideração sua inscrição em uma determinada conjuntura socio-histórica, não podendo ser, portanto, separados da "organização de seus conteúdos e do modo de legitimação de sua cena discursiva", o que faz parte de uma abordagem discursiva relevante para a análise que empreenderemos (MAINGUENEAU, 2005a, p. 74).

Concebemos, neste capítulo, o discurso como um espaço em que o social e o histórico se fundem, inscrevem-se e concretizam-se, pois "não resulta da associação contingente entre um fundo e uma forma; ele é um acontecimento inscrito em uma configuração sócio-histórica” (MAINGUENEAU, 2005a, p. 73-74). Trata-se de uma rede interdiscursiva que instaura posições enunciativas a partir das quais é possível entender a construção da identidade social da população indígena tupiniquim. Nosso objetivo consiste em analisar por meio das relações interdiscursivas, das cenas de enunciação (em especial, a cenografia) e do ethos discursivo, a constituição dos efeitos de sentido no discurso "O Saci Pererê", produzido por indígenas da aldeia Caieiras Velhas.

O discurso selecionado está registrado na coletânea Os tupinikim e guarani contam..., organizada por Edivanda Mugrabi (2005), a qual reúne um conjunto de discursos extraídos do cotidiano das aldeias tupiniquim e guarani, para as quais as histórias transcritas têm uma representação mais ou menos unificada e coerente do mundo que as envolve. 
Para a constituição do corpus, fizemos a leitura detalhada de todas as histórias da coletânea e, em seguida, selecionamos o discurso "Saci-Pererê" da aldeia Caieiras Velhas, mais pertinente para o objetivo de nossa proposta de trabalho. Feita a seleção, a atenção voltou-se para a temática desse discurso.

Ressaltamos que todos os discursos da obra foram contados em português, em razão de os tupiniquins se expressarem na atualidade em língua portuguesa, e não mais em língua materna. Todavia, "o fato de estarem escritos em português não é motivo para que tal publicação perca o seu valor" (EDUCADORES TUPINIKIM \& GUARANI; MUGRABI, 2005, p. 15).

Vários aspectos justificam nosso interesse pelo corpus: i) ele não está presente em materiais didáticos ou outros similares; ii) há poucas publicações que tratam da referida temática do ponto de vista discursivo.; iii) está relacionado à maneira pela qual o tema apresentado relaciona os modos de ser e viver da população indígena tupiniquim; e, iv) está destinado à manutenção da memória de um povo sobrevivente a inúmeras adversidades às quais foram submetidos os tupiniquins.

Nossa análise será norteada pelos pressupostos teórico-metodológicos da Análise do Discurso (doravante AD) nas perspectivas apontadas por Dominique Maingueneau (1993, 2004, 2005a, 2005b, 2006, 2015). A AD, apesar de ser considerada ainda bastante jovem, tem apresentado intensa produtividade e grande abertura para o intercâmbio com diversas áreas do conhecimento. Mostra-se como um importante campo interdisciplinar do universo acadêmico graças à crescente produção de pesquisas que investigam temáticas linguísticas que consideram diferentes manifestações da língua. Para a análise, centrarmo-nos nas seguintes categorias: o interdiscurso, as cenas de enunciação (notadamente a cenografia) e ethos discursivo. 
Justificamos nossa opção teórica por entendermos que a perspectiva apontada por Maingueneau no campo da $\mathrm{AD}$, na atualidade, são os que melhor dão conta de atender ao objetivo a que nos propomos alcançar, pois considera a prática discursiva em suas múltiplas dimensões. Isso porque a $\mathrm{AD}$ nos faz compreender como o discurso produz sentidos, como ele está investido de significância para e pelos sujeitos tupiniquins. Ademais, o caráter interdisciplinar da $\mathrm{AD}$ favorece a compreensão das práticas discursivas produzidas por indígenas, sob aspectos e ângulos diversos. Isso se torna evidente, ao tomarmos essa prática social como reveladora de inúmeras possiblidades dos planos da discursividade.

Para desenvolvermos nossa proposta, inicialmente, teceremos considerações sobre noções fundamentais para a compreensão da AD na atualidade e sua aplicação no corpus que constituímos.

O primeiro tópico trata sobre as redes interdiscursivas e a constituição dos discursos, a fim de explicitar, em linhas gerais, como o discurso traz em seu interior o Outro, ou seja, apresenta-se atravessado por diferentes discursos. Isso mostra que a interdiscursividade é, de fato, inerente à linguagem. Reconhecemos que o discurso deve ser considerado no bojo de um interdiscurso, pois o primeiro só adquire sentido no universo de outros discursos. As redes interdiscursivas permitem relacionar um discurso a outro(s), sabendo-se que cada gênero de discurso tem a sua forma particular de tratar essa multiplicidade de redes interdiscursivas. Verificamos que toda produção discursiva, de acordo com certas condições conjunturais, faz circular formulações já enunciadas anteriormente.

Em seguida, situamos o leitor em nosso percurso de estudo, em especial, no que se refere à noção de Cenas da Enunciação. Trazemos para o nosso trabalho algumas das considerações que Maingueneau $(2006,2015)$ tece sobre a cena de enunciação, expli- 
citando a tripartição desta em: cena englobante, cena genérica e cenografia. Destacamos que as três cenas não devem ser analisadas isoladamente, posto que uma influencia diretamente a outra.

O tópico seguinte preceitua a noção de ethos discursivo, apresentando-a como categoria interativa que se constrói na instância enunciativa, no momento em que o enunciador toma a palavra e se mostra por meio de seu discurso, com o intuito de regulá-lo. Trabalhamos com os efeitos de sentido desvelados pela instância discursiva, visto que o ethos discursivo deve ser concebido como resultado de diversas interações construídas no discurso. Explicitamos, na análise, que a categoria ethos se configura também como um fenômeno interativo de influência sobre o outro, o qual só é possível de ser apreendido na cenografia que condiciona o tom específico pelo qual fala o enunciador.

A parte seguinte é destinada à análise do corpus, a fim de explicitar com mais precisão o funcionamento dessa prática discursiva e os efeitos de sentido que dela emergem. Para fundamentar a análise, apresentamos alguns dados teórico-metodológicos e buscamos conhecer, por meio de recursos linguístico-discursivos, como a prática discursiva de sujeitos indígenas tematiza, em seus discursos, seu cotidiano, seus costumes e suas tradições, bem como sua maneira de construir sua mundividência.

No último item, apresentamos nossas considerações finais em que procuramos refletir sobre as diversas manifestações discursivas existentes, trazendo uma análise mais pontual sobre um discurso que não se encontra na mídia, mas que traz muitas contribuições para as pesquisas em $\mathrm{AD}$, na atualidade. 


\section{Redes Interdiscursivas e a constituição dos discursos}

Os estudos de Maingueneau (2005b) sobre as redes interdiscursivas consideram o primado do interdiscurso sobre o discurso, rejeitando-se a concepção de discurso como um sistema de ideias e concebendo-o na interdiscursividade. Para o teórico, a unidade a ser analisada consistiria exatamente num espaço de trocas entre vários discursos.

Maingueneau (2005b, p. 21) associa a interdiscursividade com a gênese discursiva, dado que há sempre um já dito que se constitui no outro do discurso. O interdiscurso passa a ser compreendido como unidade de análise pertinente, "um espaço de trocas entre vários discursos convenientemente escolhidos". Trata-se de um modelo de cadeia verbal interminável, em que podemos compreender como as redes interdiscursivas passam a constituir os discursos, dado que o simples fato de organizar um discurso em um gênero remete à necessidade de relacioná-lo com outros do mesmo gênero (MAINGUENEAU, 2015).

O primado do interdiscurso sobre o discurso recusa o fechamento do texto ${ }^{40}$, interligando-o a enunciados exteriores e anteriores. Maingueneau (2015, p. 28) acentua que o discurso "só adquire sentido no interior de um imenso interdiscurso. Para interpretar o menor enunciado, é necessário relacioná-lo, conscientemente ou não, a todos os tipos de outros enunciados sobre os quais ele se apóia de múltiplas maneiras”.

Temos, então, a proposta de Maingueneau (2005b) sobre os seguintes conceitos: universo discursivo, campo discursivo e espaço

40 O texto passa a ser visto como unidade linguística portadora de significação da qual o analista parte para mostrar os mecanismos dos processos de significação que presidem a textualização de discursividade. 
discursivo, por entender que o conceito de interdiscurso é impreciso. $\mathrm{O}$ autor denomina:

[...] de 'universo discursivo' ao conjunto de formações discursivas de todos os tipos que interagem numa conjuntura dada. Este universo discursivo constitui necessariamente um conjunto finito, mesmo que não possa ser apreendido em sua globalidade. É de pouca utilidade para o analista e define apenas uma extensão máxima, o horizonte a partir do qual serão construídos domínios suscetíveis de ser estudados, os 'campos discursivos'. Por este último, é preciso entender um conjunto de formações discursivas que se encontram em concorrência, delimitam-se reciprocamente em uma região determinada do universo discursivo. [...] É no interior do campo discurso que se constitui um discurso e fazemos hipótese de que essa constituição pode deixar-se descrever em termos de operações regulares sobre formações discursivas já existentes. [...] É-se então conduzido a isolar, no campo, espaços discursivos, isto é, subconjuntos de formações discursivas que o analista julga relevante para seu propósito colocar em relação (MAINGUENEAU, 2005b, p. 35-37, grifo do autor).

Esta tripartição possibilita, ao analista, um olhar com mais exatidão sobre o modo de coesão entre os discursos que estão em relação. Além disso, exige a elaboração de hipóteses e escolhas, ancoradas em uma dupla condição: a materialidade dos discursos e as condições de enunciação desses discursos, os quais se inscrevem no viés histórico. Compreendemos, com os direcionamentos de Maingueneau, que as noções de campo e espaço discursivos 
colaboram para estabelecer zonas de regularidade semântica, que permitem especificar a interdiscursividade a partir de condições históricas bem demarcadas (MAINGUENEAU, 2005b).

Ao propor a concepção de redes interdiscursivas, Maingueneau (2005b) renomeia o conceito de heterogeneidade mostrada e constitutiva $^{41}$ embora aceite sua presença no discurso. Maingueneau defende que:

[...] não é necessário que o Outro seja um fragmento localizável, como a citação, nem a entidade exterior marcada por alguma ruptura visível da compacidade do discurso. A relação com o Outro vai além da distinção heterogeneidade mostrada/constitutiva, ela se revela independentemente de qualquer marca de alteridade, já que o Outro no espaço discursivo não é redutível à presença do interlocutor (SOUZA-E-SILVA \& ROCHA 2009, p.06).

No discurso levam-se em conta as redes interdiscursivas, as quais continuarão a ser determinadas pela rede semântica, mesmo que tenha ocorrido o desaparecimento do Outro. Ao manter relações com o Outro, já não pode ser o discurso concebido como um sistema fechado, mas como um espaço em que a história pode e deve se inscrever, ou seja, ele se torna um espaço de trocas enunciativas. Desse modo,

41 A heterogeneidade constitutiva não deixa marcas visíveis na materialidade linguística, ainda que deixe entrever outros discursos que a constituíram, já que os textos estão intimamente ligados, amarrando o Mesmo e o Outro do discurso. Já a heterogeneidade mostrada traz o discurso de um outro interdiscurso para o discurso de um eu, por meio de marcas explícitas (MAINGUENEAU, 2005b). 
Um discurso está sempre em relação com outros discursos e esse espaço de regularidade pertinente, do qual diversos discursos seriam apenas componentes, estruturaria a sua identidade discursiva. Trata-se de uma concepção interdiscursiva, em que os discursos já nasceriam imbricados em uma relação dialógica (RECLA, 2014, p. 67).

No decorrer deste capítulo, verificaremos que em razão das condições de possibilidades semânticas que se realizam nesse espaço de trocas, o discurso nunca é autônomo e o Outro é "aquela parte de sentido que foi necessário que o discurso sacrificasse para constituir sua identidade" (MAINGUENEAU, 2005b, p. 39).

\section{A noção de cena de enunciação}

A noção de cena de enunciação proposta por Maingueneau (2006) aborda o discurso envolto em certo quadro, o qual é definido pelas restrições do gênero, mas que, ao mesmo tempo, tal quadro deve ser gerido pela encenação de sua enunciação. Isso porque no jogo da enunciação, a relação entre o quadro prévio e a encenação da fala não é a mesma em todos os gêneros de discurso (MAINGUENEAU, 2015, p. 119).

É por esta razão que Maingueneau (2015) afirma que:

O termo "cena" apresenta ainda a vantagem de poder referir ao mesmo tempo um quadro e um processo: ela é ao mesmo tempo, o espaço bem delimitado no qual são representadas as peças [...] e as sequências das ações, ver- 
bais e não verbais que habitam esse espaço [...] (MAINGUENEAU, 2015, p. 117, grifo do autor).

Para melhor explicitar a concepção de cena, Maingueneau (2015) recorda a metáfora teatral, proposta por Erving Goffman, na qual se concebe que a sociedade vive um imenso teatro em que os homens apenas desenvolveriam papéis. Maingueneau explica que os gêneros mobilizam seus participantes por meio de um papel determinado, mas não em todas as suas determinações possíveis.

As formulações de Maingueneau (2015) deixam claro que a cena de enunciação de um gênero de discurso não deve ser entendida como um bloco compacto. Por esta razão, o autor avança na metáfora teatral e traz para os estudos discursivos a interação de três cenas: a cena englobante, a cena genérica e a cenografia.

A cena englobante corresponde ao tipo de discurso que "resulta do recorte de um setor da atividade social caracterizável por uma rede de gêneros de discurso" (MAINGUENEAU, 2015, p. 118). É o próprio pesquisador, em função de seus propósitos, que decidi em que nível vai situar a cena englobante pertinente. Já as cenas genéricas funcionam como normas que suscitam expectativas, visto que para os usuários de discurso são os gêneros de discurso que trazem uma realidade imediata, plausível. A cada gênero os enunciadores são capazes de atribuir uma ou mais finalidades, bem como papéis para os parceiros referentes às atividades da qual participam, regulando as estratégias de produção e interpretação dos enunciados. Do mesmo modo, a cena genérica está associada a um papel apropriado que pode ser imposto ou não, bem como a um modo de inscrição na temporalidade, previsível ou não (MAINGUENEAU, 2015). 
Maingueneau (2015) assevera que o discurso condiciona sua forma de transporte, sendo indissociável de seu modo de existência material. Mostra também que a cena genérica se associa a um modo de encadeamento, pois o discurso pode se manifestar por meio de uma grande diversidade de planos de texto. Por fim, destaca que a cena genérica está interligada a um repertório, com o uso específico de recursos linguísticos. Como exemplo trazemos o discurso científico, os manuais escolares, os gêneros administrativos entre outros que podem impor ou não restrições na escolha lexical. Contudo, apenas a cena genérica não basta para dar conta do funcionamento de um discurso. Temos, então, a terceira cena, a cenografia, que dá conta de construir a singularidade da enunciação, pois esta não é apenas um cenário.

A noção de cenografia se apóia na ideia de que o enunciador, por meio da enunciação, organiza a situação a partir da qual pretende enunciar. Todo discurso, por seu próprio desenvolvimento, pretende, de fato, suscitar a adesão dos destinatários instaurando a cenografia que o legitima. Esta é imposta logo de início, mas deve ser legitimada por meio da própria enunciação (MAINGUENEAU, 2015, p. 123).

Maingueneau (2015, p. 126) recorda que a cenografia não tem sentido por si mesma, mas apenas se relaciona ao(s) cenário(s) característicos do posicionamento que o enunciador quer reivindicar. É por esta razão que o autor defende que a cenografia só se desenvolve se o enunciador puder controlar seu desenvolvimento, cuja escolha é plena de sentido. 


\section{A construção do ethos discursivo no discurso}

Engendrada por Maingueneau (1993), a noção de ethos discursivo é pensada como sendo uma voz e um corpo relacionados à cena da enunciação, uma vez que todo discurso escrito possui uma vocalidade específica, a qual o associa a uma origem enunciativa por intermédio de um tom que abraça tanto a escrita quanto a fala.

Maingueneau (2005b) compreende esta noção como uma dimensão da cena de enunciação, capaz de oferecer uma multiplicidade de atos interpretativos construídos por diferentes estratégias. É preciso compreender que o ethos é uma dimensão da cena de enunciação e sua abordagem é uma maneira de levar em conta uma dimensão psicofísica sobre quem fala no discurso, pois, ao falar, o indivíduo constrói uma imagem de si com base em características linguísticas e sociais.

Ao estabelecer a noção de ethos discursivo, Maingueneau (1993) amplia os estudos retóricos ao trazer para o quadro da AD uma nova roupagem da noção de ethos, ao deslocá-la para o campo discursivo. $\mathrm{O}$ autor postula que "toda fala procede de um enunciador encarnado; mesmo quando escrito, um texto é sustentado por uma voz - a de um sujeito situado para além do texto" (MAINGUENEAU, 2004, p. 95).

Ao propor um estudo mais aprofundado sobre o processo de adesão dos sujeitos a determinado posicionamento, Maingueneau acena a maneira pela qual o co-enunciador se apropria dessa noção. É por meio do ethos que o co-enunciador será convocado a um lugar inscrito na cena de enunciação.

Nessa perspectiva, o conceito de ethos passa a ser concebido como "uma voz, e, além disso, um corpo enunciante, historicamente especificado e inscrito em uma situação que sua enunciação 
ao mesmo tempo pressupõe e valida progressivamente" (MAINGUENEAU, 2005a, p. 70). Para o autor, é insuficiente conceber a instância enunciativa apenas como um papel ou estatuto. Essa noção só pode ser apreendida na cena de enunciação, com a interação de fatores diversificados como o código linguageiro ${ }^{42}$, o registro das palavras, o modo de coesão, o modo de enunciação e a modulação, uma vez que, por sua imagem, o enunciador dá-se a conhecer a si e a seu co-enunciador.

Maingueneau (2006, p. 60), assevera que:

[...] discurso, oral ou escrito, supõe um ethos: implica uma certa representação do corpo do seu responsável, do enunciador que se responsabiliza por ele. Sua fala participa de um comportamento global (uma maneira de se mover, de se vestir, de entrar em relação com o outro...). Atribuímos a ele, dessa forma, um caráter, um conjunto de traços psicológicos (jovial, severo, simpático...) e uma corporalidade (um conjunto de traços físicos e indumentários). 'Caráter' e 'corporalidade' são inseparáveis, apóiam-se em estereótipos valorizados ou desvalorizados na coletividade, em que se produz a enunciação.

Compreendemos que o ethos discursivo não está ligado somente ao estatuto do enunciador, já que esse é criado e recriado pelos coenunciadores, por intermédio de diversos elementos discursivos: tom, caráter, corporalidade, incorporação, elementos constituintes da cenografia do discurso e também, pelos estereótipos, os quais circulam socialmente como categorias que influenciam na formação da imagem do enunciador e que podem ou não ser confirmados pelo processo discursivo.

42 São as escolhas de vocabulário feitas para marcar a posição do enunciador em certo campo discursivo. 
Ao trabalharmos com a realidade discursiva, interagimos com um enunciador, o qual toma para si um ethos discursivo e assume um posicionamento que o co-enunciador pode aderir ou não. Ancorado nesse pressuposto, Maingueneau verifica que o ethos insere o fiador ${ }^{43}$ em um mundo ético, do qual ele é parte e ao qual ele dá acesso. Cada ethos está associado a um mundo ético ${ }^{44}$ (situações, lugares e grupos de estereótipos), cujas representações coletivas ativam mundos éticos relacionados ao modo de dizer.

Nessa perspectiva, detectamos que o ethos está associado à imagem de fiador em razão de conferir a si próprio uma identidade correspondente ao mundo que deverá ser construído no discurso. Não há como negar que a concepção de ethos não possa ser vista como procedimento ou como estratégia, pois é o fiador que legitima sua maneira de dizer por seu próprio enunciado.

Por fim, não tomaremos essa categoria como autônoma, por entendermos que ela é um autorretrato discursivo, integrante do plano discursivo.

\section{A constituição dos efeitos de sentido no discurso " $O$ Saci Pererê"}

Elegemos, como já dissemos, as categorias de interdiscurso, cenas de enunciação (enfatizando a cenografia) e de ethos discursivo, para verificar a constituição dos efeitos de sentido no discurso selecionado abaixo.

43 Instância subjetiva que afiança o que é dito.

$44 \mathrm{O}$ mundo ético é ativado por meio da leitura e subsume certo número de situações estereotípicas relacionadas a comportamentos peculiares. 


\section{O Saci-Pererê}

Certo dia, dois homens foram caçar, pegaram suas armas e cachorros e foram para a mata. Chegando na mata, os cachorros se apavoraram e começaram a latir olhando para cima de uma árvore. Eles apontavam a arma para matar a caça mas não conseguiam ver o bicho. Este saía, os cachorros latiam, olhavam para cima, iluminavam com a lanterna mas nada de bicho. E foi desse jeito quase a noite toda.

Nessa caçada, por mais que perseguiam a caça, não conseguiam vê-la para matá-la. Então, combinaram que um cercaria de um lado e o outro do outro, e ficaram esperando até que um deles viu os cachorros perseguirem um animal e viu até o mato se abrindo, ficou então esperando com a arma apontada mas quando percebeu os cachorros já estavam latindo do outro lado e não viu caça alguma.

Cansados de tanto correr, já estavam muito dentro da mata, quando eles imaginaram que aquilo não poderia ser caça alguma e sim o saci que estavam brincando com eles. Então irritados foram embora.

Mas isso não aconteceu só com eles. Aconteceu também com outros homens que iam caçar, e com um deles foi pior, é o que iremos contar abaixo.

O saci estava sob forma de uma caça (para quem não sabe, o saci-pererê se transforma em várias coisas e bichos), o homem ia para atar a caça, e ela desaparecia 
e ele não via mais nada. Assim ele prosseguia a noite em sua caçada. Novamente o bicho aparecia, ele ia para matá-lo e o bicho desaparecia.

Muito esperto, o homem marcou bem a direção em que os cachorros estavam latindo e atirou. "Logo tudo vai acabar", imaginava ele, e foi para casa.

Chegando em casa, escutou um assobio e uma voz, que era a do saci, que dizia:

- Saci-pererê, minha perna dói como quê.

Assustado, ele lembrou-se do tiro e pensou que o tiro poderia ter atingido a perna do saci, mas sem se preocupar, ele foi dormir.

No dia seguinte, à noite, este homem foi à casa de seu compadre. O caminho era muito escuro pois ainda não tinham instalado energia elétrica em nossa aldeia. No caminho, ele ia seguindo tranquilo quando de repente ele sentiu uma dor, mas pensou que não seria nada grave e prosseguiu. Novamente sentiu a dor e resolveu voltar para casa. Ao voltar ele sentia que a dor aumentava $e$ era como se alguém estivesse the dando uma surra. A medida que ele andava, a dor da surra aumentava. Sentiu que estava sendo surrado até chegar em casa. Ao chegar em casa não deu tempo nem de pedir água, ele caiu no chão e desmaiou.

Coitado do homem, não sabia que era o saci que tinha lhe dado uma grande surra, por ter atirado nele. Pois 
com o saci ninguém brinca.

Até hoje o saci existe, pois as pessoas ainda ouvem o seu assobio.

Para as pessoas que não conhecem muito as manhas do saci-pererê, para não levar uma surra como a que o homem levou, é só obedecer às seguintes regras:

1) Ao ouvir assobio do saci não se pode xingar e nem falar mal dele, porque ele pode lhe dar uma surra;

2) Quando novamente ouvir o assobio diga:

- Que boa companhia me leve até em casa (isso se você estiver caminhando para casa, e ao chegar em casa é só agradecer, ele ficará gratificado e irá embora).

Cuidado! Várias pessoas que encontram com o saci em seu caminho, tiveram um péssimo encontro e se deram mal. Espero que a próxima vítima não seja você. É só obedecer às regras que ele impõe.

(EDUCADORES TUPINIKIM \& GUARANI; MUGRABI, E. (Org.) 2005).

Contada por José Sezenando (Cacique)

Escrita por Leidiane

Revisada por Cristina Pajehú

A seguir, procedemos à análise ${ }^{45}$.

45 Esta análise encontra-se em nossa tese (RECLA, Adriana. A semântica global em práticas discursivas indígenas tupiniquins. Tese de Doutorado. Pontifícia Universidade Católica de São Paulo, São Paulo, 2014). 


\section{Recorte 1}

Certo dia, dois homens foram caçar, pegaram suas armas e cachorros e foram para a mata. Chegando na mata, os cachorros se apavoraram e começaram a latir olhando para cima de uma árvore. Eles apontavam a arma para matar a caça mas não conseguiam ver o bicho. Este saía, os cachorros latiam, olhavam para cima, iluminavam com a lanterna mas nada de bicho. E foi desse jeito quase a noite toda.

Neste primeiro recorte, o enunciador, em terceira pessoa, comporta-se como um observador e insere-se na cena descrevendo uma caçada na mata. Essa cenografia legitima a enunciação, delimita a cena e, ao mesmo tempo, apóia-se em uma cena validada para a população indígena, a caçada. O enunciador atribui-se o estatuto de alguém que conhece as ações de uma caçada, as quais ele descreve. O ritmo da enunciação vai incorporando o co-enunciador ao universo de um caçador, o que valida o que está sendo dito.

Eis algumas marcas que legitimam o estatuto desse enunciador:

[...] pegaram suas armas e cachorros e foram para a mata;

Chegando na mata, os cachorros se apavoraram e começaram a latir olhando para cima de uma árvore;

Eles apontavam a arma para matar a caça mas não conseguiam ver o bicho. 
Verificamos que não há referência a se os "homens" explicitados no discurso eram indígenas ou não. O discurso vai sendo construído com um tom de aventura, que paulatinamente dá corpo ao fiador, desvelando a imagem de si e confirmando se o enunciador fala de um lugar legitimado. O estatuto do co-enunciador assimila do enunciador a imagem de alguém que conhece o transcorrer de uma caçada, mas, sobretudo, que sabe das manhas e travessuras do saci na mata - algo bem conhecido pelos caçadores indígenas, mas talvez não muito conhecido por outros caçadores "não índios".

O espaço (topografia) e o tempo (cronografia) discursivos são delimitados pelas marcas linguísticas que identificam o enunciador e o co-enunciador em um lugar e tempo que lhes é próximo. Para essa demarcação, há a instauração da dêixis enunciativa espaço-temporal que delimita a cena. A cronografia discursiva é marcada pelo dêitico ${ }^{46}$ espacial atestado em "Chegando na mata" e o tempo é linguístico, o da atualização da fala, é marcado pelo indício textual no plano da cronografia, confirmado na marca linguística "Certo dia”, a qual retoma o discurso literário.

Vejamos o próximo recorte.

\section{Recorte 2}

Nessa caçada, por mais que perseguiam a caça, não conseguiam vê-la para matá-la. Então, combinaram que um cercaria de um lado e o outro do outro, e ficaram esperando até que um deles viu os cachorros persegui-

46 Elementos indiciais que no enunciado marcam a embreagem enunciativa. São exemplos: os embreantes de pessoa (pronomes pessoais, demonstrativos, possessivos), os embreantes temporais e espaciais (conhecidos como dêiticos temporais e espaciais) (MAINGUENEAU, 2004, p. 108). 
rem um animal e viu até o mato se abrindo, ficou então esperando com a arma apontada mas quando percebeu os cachorros já estavam latindo do outro lado e não viu caça alguma. Cansados de tanto correr, já estavam muito dentro da mata, quando eles imaginaram que aquilo não poderia ser caça alguma e sim o saci que estava brincando com eles. Então irritados foram embora.

Nesse excerto, o enunciador enuncia a reação dos "homens caçadores" diante do fato de o saci estar "brincando" com eles, o que é revelado nas marcas linguísticas "Então irritados foram embora". O discurso vai sendo construído com certo tom de aventura e de superstição. É interessante destacar que o discurso não explicita se os homens eram índios, apenas revela que não sabiam do que o saci era capaz de fazer. Os indígenas podem se identificar com esse conhecimento em virtude das tradições presentes na vida da aldeia.

Desse modo, o discurso se constrói sobre o estereótipo do índio como um caçador valente, conhecedor da mata e de seus mistérios, ao passo que os homens caçadores "desconhecem” esses saberes. Isso se confirma nos seguintes indícios textuais: "Cansados de tanto correr, já estavam muito dentro da mata, quando eles imaginaram que aquilo não poderia ser caça alguma e sim o saci que estava brincando com eles. Então irritados foram embora”. 


\section{Recorte 3}

Mas isso não aconteceu só com eles. Aconteceu também com outros homens que iam caçar, e com um deles foi pior, é o que iremos contar abaixo.

No recorte apresentado, o discurso engendra uma nova cenografia, agora outro relato relacionado a um caçador. Inicia-se aqui uma aproximação maior com o co-enunciador com o uso da marca de pessoa "nós", determinada pela desinência número-pessoal da forma verbal "iremos", que visa a inscrever o co-enunciador no discurso. Trata-se de um nós em que há um eu expandido para além da pessoa que enuncia, um sujeito coletivo, que permite ao enunciador explicitar a coletividade.

\section{Recorte 4}

O saci estava sob forma de uma caça (para quem não sabe, o saci-pererê se transforma em várias coisas e bichos), o homem ia para matar a caça, e ela desaparecia e ele não via mais nada. Assim ele prosseguia a noite em sua caçada. Novamente o bicho aparecia, ele ia para matá-lo e o bicho desaparecia.

No recorte acima se desenvolve outra cenografia: a do aparecimento do saci aos caçadores sob forma de uma caça - cena validada na memória discursiva. A cenografia construída nesse recorte 
é diferente da encontrada no início do discurso, pois antes não se imaginava que os acontecimentos durante a caçada pudessem ser uma travessura do saci. Os dois caçadores são excluídos da cena e outro caçador é inserido. Ao enunciador é atribuído o estatuto de alguém que conhece bem as manhas do saci, como vemos no excerto 04 .

Chamamos, nesse recorte, a atenção para a modalização autonímica ${ }^{47}$ com o uso do parêntese no enunciado "(para quem não sabe, o Saci-Pererê se transforma em várias coisas e bichos)” em que o enunciador atribui-se o estatuto de sábio, produzindo um enlaçamento na enunciação. Além disso, percebemos que o enunciador utiliza essa modalização para explicar ao co-enunciador um fato que pertence ao universo do indígena e que talvez seja desconhecido de outras culturas. Vejamos o próximo excerto.

\section{Recorte 5}

Muito esperto, o homem marcou bem a direção em que os cachorros estavam latindo e atirou. "Logo tudo vai acabar", imaginava ele, e foi para casa.

Chegando em casa, escutou um assobio e uma voz, que era a do saci, que dizia:

- Saci-pererê, minha perna dói como quê.

47 "Conjunto de procedimentos por meio dos quais o enunciador desdobra, de uma certa maneira, seu discurso para comentar sua fala enquanto está sendo produzida" (MAINGUENEAU, 2004, p. 158). São exemplos de modalização autonímica as aspas, os parênteses, as reticências, o itálico, o travessão duplo, bem como construções orais em que enunciador comenta a própria fala. 
O enunciador materializa, nesse recorte, a inserção da voz do homem, marcado discursivamente no enunciado "Logo tudo vai acabar", indicando que ele não sabia o que o saci era capaz de fazer. Supomos que a reação seja contrária a dos homens indígenas que respeitam e sabem das possíveis ações do saci na mata. Trata-se, portanto, de um enunciador que desvela discursivamente, mesmo que indiretamente, a imagem do índio como conhecedor e respeitador dos costumes que lhes são transmitidos.

A inserção da fala do saci em "Saci-pererê, minha perna dói como quê" faz com que o enunciador se assuma como responsável pelo discurso naquele momento. Chamamos a atenção para o uso do vocativo "Saci-pererê" o qual serve para chamar, invocar e interpelar o co-enunciador. Por seu caráter, esse vocativo se relaciona à segunda pessoa do discurso. Destacamos que o próprio título do discurso remete à personagem saci, uma figura presente nos ensinamentos dos indígenas tupiniquins e que, portanto, está também presente na memória discursiva.

Observa-se que a partir do momento em que o saci se mostra no discurso, ele se torna responsável pelo que diz. Desse modo, a certeza de sua presença é confirmada e o fato passa a se tornar concreto. Vejamos os fragmentos que seguem.

\section{Recorte 6}

Assustado, ele lembrou-se do tiro e pensou que o tiro poderia ter atingido a perna do saci, mas sem se preocupar, ele foi dormir.

No dia seguinte, à noite, este homem foi à casa de seu compadre. O caminho era muito escuro pois ainda não 
tinham instalado energia elétrica em nossa aldeia. No caminho, ele ia seguindo tranquilo quando de repente ele sentiu uma dor, mas pensou que não seria nada grave e prosseguiu. Novamente sentiu a dor e resolveu voltar para casa. Ao voltar ele sentia que a dor aumentava $e$ era como se alguém estivesse the dando uma surra. A medida que ele andava, a dor da surra aumentava. Sentiu que estava sendo surrado até chegar em casa. Ao chegar em casa não deu tempo nem de pedir água, ele caiu no chão e desmaiou.

Coitado do homem, não sabia que era o saci que tinha the dado uma grande surra, por ter atirado nele. Pois com o saci ninguém brinca.

Até hoje o saci existe, pois as pessoas ainda ouvem o seu assobio.

O tom de piedade evidenciado no enunciado "Coitado do homem, não sabia que era o saci que tinha lhe dado uma grande surra, por ter atirado nele" e de advertência evidenciado em "Pois com o saci ninguém brinca" permite ao co-enunciador construir uma representação do corpo do enunciador.

Emerge, então, uma instância subjetiva corporificada, o fiador, que afiança o que é dito. Esse fiador, no caso, uma imagem de alguém que sabe do que o saci é capaz de fazer a um caçador destemido, apóia-se em um caráter que emerge de um corpo e de uma corporalidade. A corporalidade mostrada pelo enunciador é de uma pessoa que também conhece a arte de caçar e as possíveis atitudes do saci. Logo, o co-enunciador incorpora a imagem de alguém conhecedor das artimanhas do saci. 
Devemos lembrar que no discurso escrito não há a representação direta dos aspectos físicos do enunciador, mas há pistas que indicam e levam o co-enunciador a atribuir uma corporalidade e um caráter ao enunciador, categorias essas que interagem no campo discursivo.

\section{Recorte 7}

Para as pessoas que não conhecem muito as manhas do Saci-Pererê, para não levar uma surra como a que o homem levou, é só obedecer às seguintes regras:

1) Ao ouvir assobio do saci não se pode xingar e nem falar mal dele, porque ele pode the dar uma surra;

2) Quando novamente ouvir o assobio diga:

- Que boa companhia me leve até em casa (isso se você estiver caminhando para casa, e ao chegar em casa é só agradecer, ele ficará gratificado e irá embora).

No enunciado "Para as pessoas que não conhecem muito as manhas do Saci-Pererê", fica mais evidente a referência àqueles que desconhecem certas tradições da realidade indígena sobre o saci. Revela-se um tom de alerta, evidenciado no enunciado citado. Aqui o enunciador se apresenta com tom de alerta e até mesmo de comando, como aquele que vai explicar como funcionam as regras para se respeitar o saci e conhecer seus comportamentos; esse tom é confirmado nos enunciados supracitados.

Já no enunciado "(isso se você estiver caminhando para casa, e ao chegar em casa é só agradecer, ele ficará gratificado e irá embo- 
ra)", temos a modalização autonímica em que o enunciador enlaça o co-enunciador, alertando-o sobre como proceder caso encontre o saci. Essa atitude possibilita a emergência de um ethos conhecedor da realidade indígena, em especial, da figura do saci.

A descrição do que deve ser feito para obedecer ao saci ativa no co-enunciador estereótipos sobre os costumes indígenas, o que o leva a recorrer aos estereótipos partilhados na e pela coletividade indígena, como a crença no saci, e ao mesmo tempo a recorrer ao mundo ético desse grupo.

Ainda, nesse recorte, notamos que o uso do modo imperativo denota a relação estabelecida entre o estatuto do enunciador e do co-enunciador. Isso porque o imperativo manifesta ordem e apelo pela concretização da ação, como podemos atestar em "Ao ouvir assobio do saci não se pode xingar e nem falar mal dele, porque ele pode lhe dar uma surra" e "Quando novamente ouvir o assobio diga".

\section{Recorte 8}

Cuidado! Várias pessoas que encontram com o saci em seu caminho, tiveram um péssimo encontro e se deram mal. Espero que a próxima vítima não seja você. É só obedecer às regras que ele impõe.

Para que o co-enunciador possa aderir ao posicionamento do enunciador, percebemos que ele precisa se colocar também como um conhecedor dos comportamentos do saci e dos conhecimentos indígenas, conforme vemos nos enunciados "Espero que a próxima vítima não seja você. É só obedecer às regras que ele impõe”. 
Temos também explícito nesse enunciado o conselho de natureza moral, referente à obediência às regras necessárias ao se encontrar com o saci. A moral representada nesse enunciado serve como fortalecimento dos aspectos culturais da comunidade tupiniquim em razão da identificação com o que está sendo enunciado. Observa-se ainda nos mesmos enunciados, que o enunciador aproxima-se do co-enunciador de forma a enlaçá-lo no discurso, principalmente, com o uso da marca de pessoa "você".

O uso da interjeição “Cuidado!” revela claramente o conhecimento do enunciador, que se posiciona como um típico indígena caçador, divulgador de seus saberes e conhecimentos. Verificamos, nesse excerto, que o discurso constrói o tom de advertência, que autoriza o que é dito.

Apreendemos, portanto, que o homem caçador é retratado como um não conhecedor das manhas do saci; já o índio é detentor de um conhecimento que lhe é particular e nem por isso menos importante. Revela-se um ethos cujo tom é marcado por misticismo.

Notamos que no discurso prevalece a conjugação no tempo passado. Trata-se da modalização, afinal, todo enunciado tem um valor modal. Além disso, o enunciador, direta ou indiretamente, marca sua presença por meio do que diz (MAINGUENEAU, 2004a, p. 107), como podemos atestar pelas seguintes marcas verbais encontradas já no primeiro excerto: "foram caçar"; "pegaram suas armas e cachorros"; "foram para a mata"; "se apavoraram"; "começaram a latir"; "apontavam a arma"; "não conseguiam ver o bicho", dentre outras, presentes no discurso.

Notamos que o ethos construído discursivamente possibilita uma corporalidade do enunciador, cuja imagem discursiva é a de alguém que conhece as artimanhas do saci, com traços de cará- 
ter dessa especificidade. É essa imagem que o enunciador constrói como fiador do seu dizer.

\section{Considerações finais}

Oriunda da necessidade de o indígena tupiniquim registrar experiências vivenciadas por ele ou por alguém de seu grupo (EDUCADORES TUPINIKIM \& GUARANI; MUGRABI, 2005), a prática discursiva que selecionamos revelou aspectos da identidade, o modo de interpretar a si próprios, a maneira de ser e de viver, enfim, como se mostram os tupiniquins.

O discurso selecionado impõe certos temas peculiares, como a caçada, o aparecimento do saci à noite, o respeito ao saci, embora seja pelo posicionamento e não pelo tema que a especificidade do discurso seja definida. O código linguageiro mobilizado é capaz de auxiliar na construção das cenas e do ethos discursivo, marcados em indícios textuais presentes ao longo de todo o discurso (caçada, caça, mato, cachorros já estavam latindo, mata, saci, entre outros) o que confere à enunciação a construção de uma cena que valida o que é dito. $\mathrm{O}$ "modo de falar indígena" remete ao léxico descontraído e próprio do cotidiano, constituindo o modo de coesão.

Nesse discurso, o co-enunciador compactua com o que está sendo dito, como é percebido por meio do código linguageiro, do tema, do estatuto do enunciador e do co-enunciador, da dêixis enunciativa, do modo de enunciação e do modo de coesão.

Notamos que o discurso é atravessado pelo discurso místico, literário, folclórico, supersticioso. Com isso, podemos afirmar que todo discurso nasce de outro discurso, o que comprova a noção de interdiscursividade. 
A cenografia revelou-se por meio das pistas localizáveis no discurso; é pelo que o discurso diz, a situação que representa, que ela se justifica. À medida que a cena vai se desenrolando, o enunciador vai enlaçando o co-enunciador. A cenografia é validada pelos indígenas tupiniquins e revela a representação sobre quem fala e desvela o ethos discursivo.

Constatamos que para se construir a imagem discursiva do enunciador são ativados traços estereotípicos de um conhecedor dos comportamentos do saci. Nesse caso, o ethos discursivo é resultante dos traços que estão em sua memória, que se legitimam e confirmam a partir dos traços que surgem no/do próprio enunciado, desvelado na cenografia construída.

Esse discurso, como destacamos, desvela um enunciador conhecedor das artimanhas do saci, do caráter do saci. Desse modo, a descrição dos procedimentos de uma caçada é mero pretexto que enlaça o co-enunciador discursivamente, além de servir para ressaltar as vantagens de ser um conhecedor desses comportamentos e para destacar que o índio pode e sabe conviver com essas atitudes.

Por fim, há uma relação concreta entre o enunciador e o co-enunciador devido às diversas fontes de saber dos costumes indígenas, o que nos leva à dimensão intertextual.

\section{Referências}

EDUCADORES TUPINIKIM \& GUARANI; MUGRABI, Edivanda (Org.). Os tupinikim e guarani contam... 2. ed. Vitória: Departamento de Impressa Oficial do Espírito Santo, 2005.

HOUAISS, Antônio. Dicionário Houaiss da língua portuguesa. Rio 
de Janeiro: Objetiva, 2009.

MAINGUENEAU, Dominique. Novas tendências em Análise do Discurso. 3.ed. Tradução Freda Indursky. Campinas, SP: Pontes: Universidade Estadual de Campinas, 1993.

- Análise de textos de comunicação. Tradução de Cecília P. de Souza-e-Silva \& Décio Rocha. São Paulo: Cortez, 2004.

. Ethos, cenografia, incorporação. Tradução de Sírio Possenti. In: AMOSSY, Ruth (Org.). Imagens de si no discurso: a construção do ethos. São Paulo: Contexto, 2005a. p. 69-92.

. Gênese dos discursos. Curitiba: Criar, 2005b.

- Cenas da enunciação. Tradução de Maria Cecília P. de Souza-e-Silva, Nélson P. da Costa \& Sírio Possenti. Curitiba: Criar, 2006.

. Discurso e Análise do Discurso. Tradução de Sírio Possenti. São Paulo: Parábola, 2015.

RECLA, Adriana. A semântica global em práticas discursivas indígenas tupiniquins. Tese de Doutorado. Pontifícia Universidade Católica de São Paulo, São Paulo, 2014.

SOUZA-E-SILVA, Maria Cecília \& ROCHA, Décio. Gênese dos discursos, de Dominique Maingueneau (resenha). ReVEL, v. 7, n. 13, 2009. Disponível em: <www.revel.inf.br>. Acesso em: 6 out. 2012. TEAO, Kalna Mareto \& LOUREIRO, Klítia. História dos índios do Espírito Santo. Vitória: Editora do Autor, 2009. 